\title{
Liberation extension: building capacities for civilizational transition
}

\author{
Nicholas Copeland ${ }^{1}$ (i)
}

Accepted: 10 January 2022 / Published online: 27 January 2022

(c) The Author(s), under exclusive licence to Springer Nature B.V. 2022

\begin{abstract}
COVID 19 has exacerbated and underscored structural inequalities and endemic vulnerabilities in food, economic, and social systems, compounding concerns about environmental sustainability and racial and economic justice. Convergent crises have amplified a growing chorus of voices and movements calling for new thinking and new practices to adapt to these shifts, mitigate their impact, and address their root causes through far reaching changes in social and economic life and values, including breaking with the free market paradigm. In the face of a historic choice between transition or multiple systems collapse that deepen injustice and threaten planetary survival, I make the case for expanding on liberatory tendencies in Extension programs to build capacities for response-ability to transition toward more just and sustainable futures.
\end{abstract}

Keywords Liberation extension $\cdot$ COVID $19 \cdot$ Climate change $\cdot$ Food sovereignty $\cdot$ Mutual aid $\cdot$ Degrowth $\cdot$ Land grants

\section{Introduction}

The theme of this discussion essay is the urgent need and exciting potential to expand and reorient Cooperative Extension programs, hereafter "Extension," to address interrelated challenges of COVID 19, climate change, and longstanding and rising inequalities. The convergence and increasing undeniability of these crises have opened a historic space to address the roots of structural problems in prevailing systems. Social movements that denounce the endemic nature of injustice and harm have grown in strength and visibility, persuading millions about the necessity for structural transformation in areas as diverse as policing, labor rights, caregiving, energy, climate, public health, and food production. Alarming evidence of human precariousness and political and ecological chaos highlighted by protest have shown current structures to be unjust and unsustainable, calling into question narratives of technological, racial, and civilizational progress through the free market. Ideas that were unthinkable less than a decade ago have become mainstream. Concomitantly, we see a return to robust public sector proposals after decades of privatization. Policy discussions

Nicholas Copeland

ncopel@vt.edu

1 Department of History, Virginia Polytechnic and State University, 431 Major Williams Hall (0117), 220 Stanger Street, Blacksburg, VA 24061, USA increasingly focus on system wide change and how to overcome procedural obstacles to their implementation.

Extension agents are on the front lines of responding pragmatically to a wide array of demands generated by the inability of prevailing economic frameworks and social systems to meet human needs and Extension has a historic opportunity to do much more. I want to foreground Extension in discussions of transition, amplifying and extending calls from Extension professionals and scholar-practitioners for an expansive conception of Extension's mission as new public funds come online for precisely these purposes (Ostrom 2020; Peters 2021). Extension has unique relevance for its embeddedness in communities, competence across diverse social and economic domains, its public mission, and its strengths in popular education, networking, and capacity building. This essay is intended as a provocation to creatively think about what might be possible through Extension in this critical moment. This potential exists in embryonic form in Extension programs and practices that embrace a liberatory ethos, what I call Liberation Extension, a persistent but often underappreciated current of Extension work, particularly in Historically Black Colleges and Universities (HBCUs) and Tribal Colleges and Universities. These deserve thoughtful consideration as a basis for reappraising Extension's mission.

This essay grew out of a dialogue over the course of the tumultuous 2020-2021 academic year with the Extension leadership team and state Program Team Leaders through 
my role as chair of the Commission on Outreach and International Affairs (COIA) at Virginia Tech. It was informed by previous discussions of Extension in Virginia Tech's Climate Action Commitment, where I participated on the Land and Agriculture subcommittee, and by my own research into Extension programs and development politics in Guatemala. The leadership team at VCE showed an openness and enthusiasm for dialogue and patience with my questions and incomplete understanding of their work. My call for explicit alignment with liberationist impulses in Extension echoes calls for politically engaged scholarship with movements for economic, racial, gender, and ecological justice (Hale 2006). Insightful comments from three reviewers led me to examine the deeper history of inequality in Extension programs. This essay should in no way be construed as reflecting the opinions of Virginia Cooperative Extension, Virginia Tech, or COIA.

The essay proceeds as follows: First, I provide an overview of the intertwined civilizational challenges in the current historic moment and rising calls for structural transformation made by social movements. In the next section, I assess some of the ways Extension programs have responded to these problems and limits to these responses. In section three, I describe some core elements of Liberation Extension and steps for institutionalization. In section four, I explore how Liberation Extension could support transition processes in agriculture, mutual aid, and climate change mitigation.

\section{COVID 19 as mirror and accelerator}

Events in recent years have left many of us traumatized, exhausted, and afraid. It is incumbent upon us to take stock of the numerous recent tragedies and upheavals to understand what they can teach us about who we are, the nature and scope of the problems that we face, and what possibilities they open up.

The stresses caused by COVID-19 and the governmental response have revealed profound vulnerabilities, externalities, and inequalities in social and economic systems in the US, with far reaching implications for how we live and work and how we think about the present and the future (Davis 2020). COVID 19 is a mirror that highlights our problems and shows how they are interrelated and, to a large extent, products of prevailing economic and social frameworks. It also accelerates these problems and underscores the urgency in addressing them.

As we know all too well, by early 2022, there have been over 5 million COVID 19 deaths worldwide, almost one million in the US alone, many of them preventable, disproportionately affecting racial minorities, the elderly, people with disabilities, immigrant workers, and incarcerated people. In 2021, overall life expectancy in the US decreased by one year, two for African Americans, and three for Latinos (Andrasfay and Goldman 2021). The two defining epiphanies of early COVID-heightened concern for essential workers and the heightened vulnerability of marginalized groups-were quickly subsumed by greed and politics. When racial disparities in COVID 19 mortality, evidence of extreme material inequality, became clear, Trump seemed to lose interest in stopping the spread (Serwer 2020), his calculated neglect adding urgency to Black Lives Matter protests that erupted after the murder of George Floyd at the hands of police. Trump had already ordered meat processing plants to stay open and okayed faster line speeds in chicken factories, increasing injury and contagion among a mainly immigrant workforce (Colvin 2020). Such actions, alongside the push to force everyone back to work, rendered visible the harsh edges of an economic system that routinely devalues the lives of working people in general, and of women, Black, and brown and disabled people in particular. Since then, COVID 19 and its uneven violence have become increasingly normalized.

COVID 19 is itself an unintended consequence of dominant economic systems. Spread through human encroachment on wilderness habitats, tracing circuits of accelerated multinational exchange, and arriving amid growing alarm about the climate emergency, COVID 19 serves as a stark reminder that deregulated growth and consumerism are chewing through and polluting ecological systems at an alarming rate, threatening the web of life (Bellamy Foster and Suwandi 2021; Wallace et al. 2020; Hickel 2020). As we race towards a sixth mass extinction (Barnosky et al. 2011), a report by the Intergovernmental Panel on Climate Change (IPCC) warns that a rise of $1.5^{\circ} \mathrm{C}$ is "dicing with the planet's livability" and calls for immediate decarbonization (IPCC 2021), and 230 medical journals describe global warming as the "greatest threat to global public health" (Atwoli et al. 2021). The third IPCC report concludes that meeting climate targets requires a paradigmatic shift away from the growthoriented capitalist model (Bordera Romá 2021). Warming disproportionately harms poor and farming communities in the Global South already reeling from decades of free market policies and who are the least responsible for rising temperatures (World People's Congress 2010).

COVID 19 also disrupted the highly curated veneer of normalcy that shields the corporate food system. In addition to making visible the miserable conditions of immigrant workers, COVID 19 raised public concern, well known among experts, about antibiotic resistance, and the high risk of zoonosis-animal to human viral transmission-in industrial meat processing (Attwood and Hajat 2020; FAO 2013). The next pandemic will likely come from the food system and spread through its workers (Davis 2006; Wallace et al. 2020). Whereas immigrant workers are paradoxically "essential," "illegal," and 
expendable, the meat industry is both "essential" and a threat to human health and the environment.

The pandemic increased food insecurity in the US by a third (Mehta and Chang 2020), again along racial lines, but also indexing a vast multi-racial underclass on the edge of precariousness. Meanwhile, billionaires in the US grabbed an additional \$1.6. TN during the first year of the pandemic while globally billionaires raked in $\$ 3.9$ TN (Oxfam 2021). By contrast, workers globally lost an estimated \$3.7 TN (Kaplan 2021). Rising economic uncertainty menaces a social terrain decimated by decades of neoliberal policies of privatization, deregulation, antiunion legislation, and cuts to safety nets (Harvey 2006). The catastrophic public health response was hampered not only by the incompetence, neglect, corruption, and politically motivated-misinformation of the Trump administration, but also decades of divestment from public health and a disjointed for-profit system (Navarro 2020; Woodhandler et al. 2021)—emblematic of policies that have deepened inequality, hollowed out democracy, and sparked calls for its renovation (Brown 2015).

The coming years will likely bring rising inequality and precariousness, accelerated climate chaos, and potentially another pandemic (Atwoli et al. 2021). Prevailing economic and social frameworks threaten regional and global ecosystems, economies, the right to food, water, and public health, sharpen strains on the social fabric and the web of life, reinscribe legacies of colonialism and inequality, and present existential threats to democracy. Pharmaceutical giants enact ecological apartheid through defenses of intellectual property rights while thousands die preventable deaths in the Global South (Byanyima 2021). Living ethically and with dignity into the future requires far reaching transformations in energy, agriculture, transportation, public health, housing, as well as how we define well-being and the ways that we relate to nature and to one another, within and across national borders.

On the positive side, these convergent crises have widened space for serious consideration of paradigmatic alternatives, long overdue. We see rising interest in movements for racial and environmental justice, gender equality, food sovereignty, immigrant and labor rights, Indigenous autonomy, LGTBQ rights, universal healthcare, basic income, and affordable housing. These movements contribute to a growing awareness that any livable future demands major structural changes. The free market consensus is in decline even in the Global North, with COVID 19 striking a powerful blow (Davis 2020). Even President Biden, a conservative centrist, regularly echoes themes from Black Lives Matter, the Green New Deal, and the Sanders and Warren campaigns. Ideas that once seemed as far-fetched have come to appear to many as the only sensible, scientifically grounded, options. The status quo is unrealistic, immoral, omnicidal.
It is not a question of whether to transition, but how quickly and democratically we can do so.

We must neither deny these dangers nor accept this fate. We can avoid the worst outcomes of current trends and build a more just society in the process. In fact, addressing historical injustices goes hand in hand with responding meaningfully to the ecological and economic crisis. But we must act decisively and collectively to adopt distinct paradigms of thought and build new structures to sustain new ways of living and relating. However, the organizational and imaginary capacities to build this future do not yet exist and will not simply materialize out of necessity. We must creatively weave democratic impulses into organization and concrete processes of change. This multigenerational task faces powerful opposition, in the form of denialism, disinformation, outright repression, as well as a wave of shallow solutions designed to channel the desire for change back into unsustainable systems. Extension can play a humble but significant role in building the conceptual and organizational capacities for a just civilizational transition.

\section{A historic opportunity for extension}

Established in 1914 by the Smith-Lever Act, Cooperative Extension, or just Extension, has historically had agents in every county with backgrounds in agriculture, the life sciences, and social sciences, engaging communities across a range of program areas. Extension primarily works in agriculture, community development, conservation, and youth programs. Extension is the development arm of the land grant institution in the sense that they work to build human capacities and expand economic opportunities (Peters et al. 2018). Extension partners with hundreds of organizations and community groups. Virginia Cooperative Extension (VCE), for example, is comprised of Virginia Tech and Virginia State, an HBCU, and has 34,000 volunteers, most of these in $4 \mathrm{H}$, as well as numerous community educators.

Rather than service provision, Extension specializes in capacity building: training people in practical skills, applying technology, leadership, building relationships, and instilling habits of thought and practice. Extension agents may help create organizations where the need exists and work to build the capacity to build organizations, commonly known as organizational capacity. The goal is for communities to take over programs themselves.

By its nature, Extension is already responding to problems endemic to food, economic, and social systems. COVID 19 increased demand sharply across Extension program areas. While welcome, these demands outstripped Extension's capacity, both in funds and personnel, which have been weakened by years of tight budgets following the trend toward privatization of public-sector programs (Wang 
2014; Coppess et al. 2018). Extension in 2021 has fewer community development programs, full-time employees, and agents with social science backgrounds.

The passage of the American Recovery Act and popular support for far reaching investments in social welfare, clean energy, and infrastructure signals a tentative commitment to government as a solution to social problems, a reversal of decades of neoliberal consensus (Cassidy 2021; Schlesinger and Restuccia 2021). Extension is poised to expand, and as it does, it must be reoriented to address problems in new ways, ways that lay the groundwork for a just transition, embedding it in social relationships, engaging communities directly, and working to ensure that the transition is as deep, egalitarian, and democratic as possible. This involves new thinking and engaging new voices at various levels. This is a historic, even world-historic, opportunity for Extension to build on current work to develop a robust and multidimensional public sector response tantamount to the challenges we face.

Stepping up to this moment requires first breaking with Extension's historical role as a microcosm and mechanism of structural inequality. The Morrill Act of 1862 created land grant universities on Indigenous territory and raised additional funds through speculation on stolen land (Stein 2017; INFAS 2018; Ahtone and Lee 2021). Agricultural programs in 1862 institutions served predominantly white farmers in the north and exclusively white farmers in former confederate states (Lee 2013; Whayne 1988). The Morrill Act of 1890 banned racial preferences for federally funded colleges absent an alternative system, leading to the establishment of 19 "separate but equal" Black land-grant universities in southern states. In 1914, when the Smith-Lever Act formally created Extension in 1862 land grants, it rerouted funds for 1890 institutions through 1862 schools, which withheld aid from Black Extension programs that already faced egregious discrimination in the south (Whayne 1988; Harris 2008). Extension discrimination contributed to a "cavernous information gap between Black and white farmers" (Grant et al. 2012, p. 15), and was instrumental in the emergence of the conservative American Farm Bureau Association (AFBA) (Kile 1948; Campbell 1962; Patel and Goodman 2019), the largest (US) farmer organization, which has a long history of racism, and is a powerful lobby for agribusiness monopolies, free trade, and subsidies which disproportionately benefit white farmers (Boyd and Faber 2020), while opposing farmworker rights, environmental regulations and independent farmer mobilization (Shearn 2012; Raderstorf 2020).

In 1977, the Evans-Allen Act formalized Extension in 1890 institutions and allotted them fifteen percent of funds from 1862 institutions. The Equity in Educational LandGrant Status Act of 1994 gave land grant status to Native American Tribal Colleges and Universities, which created Extension programs. Inequalities between Extension programs persist, however. An Association of Public Land Grant Universities survey revealed that from 2010 to 2012 Extension at 1890 institutions lost " $\$ 57$ million due to states not meeting the one-to-one match" of federal dollars, in contrast to their 1862 counterparts (Lee 2013, p. 1). 1994 institutions rely on competitive grants that the National Congress of the American Indian describes as "grossly underfunded" (NCAI 2015).

My dialogue with VCE was guided by a sense that structural problems in Extension cannot continue to be ignored, that Extension is uniquely positioned to respond to looming challenges, and that doing so will raise its public and university profile and strengthen Extension's position as a destination for public transition funds. This dialogue was informative and productive. In the following, I bring together conversations about Extension with an analysis of contemporary social movements to propose Liberation Extension as a new guiding ethos for transformational Extension work.

\section{Technical and apolitical?}

Although on the front lines of many crises, Extension is not centered in discussions of economic and energy transitions, such as the Green New Deal. This is unfortunate, given Extension's potential relevance to these conversations, but it likely reflects the conservatism of 1862 Extension programs, typically encountered in the dominant framing of Extension's role as the apolitical transfer of technology and information, application of proven programs, and evidence-based approaches. Extension often reflexively frames social and political problems as technical ones, and avoids contentious debates to maintain the perception of neutrality (Peters et al. 2018, p. 26). Extension also promotes entrepreneurialism and resiliency, training communities to navigate markets and risk in an economic system in which corporations have more and more control, opening limited spaces of freedom within unequal and often hostile structures (Rose 1999). Guatemalan Extension programs played a key role in implementing "apolitical" counterinsurgency development programs Indigenous communities (Copeland 2012, 2019). Under the guise of neutrality, such programs support the status quo, offering a limited vision of what Extension could accomplish. Extension tends to reproduce historic inequalities and systemic harms, not necessarily on purpose, but by not challenging them, and because of affinities with existing partners and approaches as well as discomfort with expanding to new communities or seeming political. 1862 Extension programs have historically had mostly white leadership and most have only recently begun earnest internal conversations around race in the wake of Black Lives Matter protests. Extension professionals recognize the limitations of the tech transfer model, and many struggle to address systemic issues, but best practices alone cannot address these problems. Doing 
so requires engaging in dialogue about values, thinking critically about partners, and recognizing that there is no neutral stance outside of these issues (Kim Niewolny, personal communication; Colasanti et al. 2009).

Early founders espoused a more progressive vision of Extension, championing public education, conservation, experimentation, and civic engagement (Bailey 1903, 1915; Smith 1949; Peters 2006, 2014; Ostrom 2020). In her 2020 Presidential address to the Society for Agriculture and Human Values, "Radical Roots and twenty-first Century Realities," Marcia Ostrom states that:

The history of Extension shows a focus on individual empowerment and community capacity-building through interactive learning methods and an emphasis on serving the most marginalized members of society (939).

The Smith-Lever Act establishes a broad mandate to pursue such goals. Today, however, there is a prevailing sense that Extension must tread lightly, as it does not make policy and is limited by state and federal funding, and so as to not offend conservative partners (Clark et al. 2017). Some conservative state administrations have deliberately restricted conversations around Extension (Scott Peters, personal communication). However, many opportunities exist for a more proactive and progressive Extension practice. And much can be accomplished by making small but meaningful changes, consciously and deliberately, within existing programs.

\section{Liberation extension}

Many Extension professionals embrace this broader public mission in various ways: promoting sustainable community food systems, including excluded groups, and partnering with organizations that advocate for the disenfranchised. Ostrom (2020) writes that "efforts to address inequalities of access are gaining momentum" in Extension and deserve more analysis (941). Some seek to make democracy work by facilitating conversations around contentious issues and building capacities to engage in democratic decision-making (Goerlich and Walker 2015; Peters et al. 2018). The efforts of many field-faculty along these lines deserve recognition.

I call these tendencies Liberation Extension, with a nod to Liberation Theology (Gutierrez et al. 1988), a movement in the Catholic Church with origins in twentieth century Latin America rooted in a reading of the life of Jesus Christ as a call to side with the oppressed against the forces that create poverty. Such an Extension practice eschews neutrality, embraces a liberatory ethos, and sees itself as actively participating in, rather than simply responding to, processes of social change in solidarity with the poor and vulnerable. In order meet the challenges and seize the opportunities of the current moment, we should work to amplify these liberatory tendencies in Extension, with a conscious reorientation of institutional resources and attention towards the construction of economic, food, and socio-natural systems rooted in principles of fairness and ecological balance, and, simultaneously, to strengthen movements for far reaching transition policies. Liberation Extension allies with movements to construct alternatives that address structural contradictions in social and economic systems and invites working people to participate collectively in these processes. There is an ongoing conversation in Extension about how to build on existing work, to do it better, more systematically and effectively. In their recent volume about Extension professionals, for example, Peters et al. (2018) encourage us to "open our collective imagination to possibilities for professionals to jump into civic life in ways that support the task of making democracy work" (16).

Making democracy work will require a mass movement with durable organization and a clear focus on addressing fundamental social contradictions, capable of capturing the public imagination and channeling social antagonism to reclaim democracy from corporations. This movement must be strong enough to pressure the government to fund universal health care, renewable energy, public education, green public housing, public transportation, sustainable agriculture, food assistance, green jobs, and climate adaptation, and more, with equal access for everyone. Such policies are increasingly popular across traditional political divides, and could be more popular, but are blocked and maligned by powerful interests who work to mask systemic harms and use zero sum logics to divide working people. Constructing an economy based in economic and racial justice that operates within ecological limits requires displacing economic growth and capitalist wealth accumulation as central goals (Bellamy Foster 2000). Capitalist growth (profit) disproportionately benefits the hyper-wealthy, while producing immense environmental destruction and waste, and is incompatible with the rapid decarbonization needed to arrest warming (Raworth 2017; Hickel 2020; Kallis et al. 2020). The global capitalist economy was founded on colonialism, dispossession, and slavery, and requires military, prisons, and police to maintain endemic economic and racial inequality, nationally and internationally, stripping poor and racialized populations and nature of inherent rights in the quest to artificially cheapen labor and resources for capital (Bellamy Foster 2000; Moore 2015; Haraway et al. 2016; Yamahtta-Taylor 2016). The fights for economic, racial, and environmental justice, and a future where everyone fits are all intertwined.

This vision of change takes cues from proposals for a Green New Deal, which links social and anti-poverty policy to decarbonization (Aronoff et al. 2019), movements for racial justice and decolonization, and from proposals for a 
Red Deal that seeks to build a mass movement for "a world premised on Indigenous values of interspecies responsibility and balance" (Red Nation 2021, p. 30). Like these proposals, this one also takes inspiration from Indigenous land and water defenders, climate justice activists, and food sovereignty movements worldwide. This reorientation of valuesa rethinking of security, well-being, citizenship, and justice, and a departure from capitalism and imperialism-is critical if we are to survive climate change without condemning much of humanity, following racial logics, along with nature itself, to disposability (Ajl 2020).

Although examples of successful alternatives abound, and conditions exist for such a movement to grow, it does not exist. Building a movement for paradigmatic change requires creating a new common sense, expanding local alternatives, and building alliances for alternative visions. Liberation Extension can play a humble but important role in forging coalitions around common demands across lines of difference through education in service of transition. Leveraging community relationships, institutional knowledge, and expertise, Liberation Extension can help forge a new collective consciousness and speed up alliance building among a diverse range of working people, cultivating organizational and deliberative capacities while engaging communities in the task of building fair, healthy, and sustainable economic systems.

This new orientation focuses on meeting basic needs and economic justice, rather than growth for growth's sake, or market based and technical solutions. These should be replaced with a commitment to care work, mutual aid, and improving the material conditions of the growing underclass (Spade 2020), prioritizing collective well-being over individualist, entrepreneurial skills training. Relatedly, a commitment to overcoming interlocking forms of oppression could infuse Extension programming, materials, and pedagogy at multiple levels. Extension should be antiracist and feminist, prioritizing efforts to undo structures of racism and sexism that persist through neutrality and inaction, beginning with their own programs. My point is not that Extension should wave a flag to loudly advocate for radical change, which would not accomplish much and may not resonate with diverse publics. But it should prioritize the material needs, collective orientations, and organizational capacities of working communities and seek opportunities to creatively engage them in the processes of addressing the structural roots of their problems through co-imagining and co-constructing democratic and sustainable systems. Grounding Extension in civilizational challenges could expand shrinking constituencies (Colasanti et al. 2009; Coppess et al. 2018), including in rural areas.

Extension education could focus on the historical and political roots of shared problems and foster relationships with organizations that advocate for alternative proposals that already exist. Such efforts could cultivate "responseability" (Haraway 2016)_our "capacities to respond" rooted in an awareness of the interdependence of humans with each other and with nonhuman beings, an ethics of co-creation and care not confined by checklists of correct behavior or individualist market logic. In these and other ways, Extension can play an important role in building the social infrastructure and organizational capacity for the transition toward a more just and sustainable society.

Fully taking up this mission will require significant increases in resources, an expanded scope of operation, and more Extension agents and educators with social science backgrounds, but just as importantly, fresh thinking about Extension's role. With a clear vision, Extension could optimally channel transition funds into concrete programs with lasting and transformative impact. Articulating a compelling narrative around Extension's mission as an engine of transition could elevate its status as an ideal destination for resources dedicated to transitional processes while reaching new constituencies.

These programmatic shifts need not come from the top down. The last thing overburdened Extension agents need is another set of obligatory programs. They should instead bubble up from a dynamic conversation in which Extension agents from across 1862, 1890, and 1994 land grants and community partners propose pilot programs to scale up or new initiatives they could implement with expanded budgets and additional personnel. Extension leadership teams should champion new orientations internally and with federal, state, and local officials, university administrations and faculty, community partners, and the public, and take responsibility for making difficult decisions regarding partners, direction, and hiring to promote diversity and reflect new priorities. Some tradeoffs are inevitable and salutary. Moreover, it is incumbent on university administrators to recruit a diverse Extension leadership capable of championing and implementing this vision.

Extension professionals in 1862 institutions could cultivate relationships with organizations in poor and minority communities, educate themselves, and commit to broaching sensitive topics with traditional partners. They must also diversify their ranks and community partners before they can credibly lead public conversations about racial justice. On these matters, 1862 programs should study 1890 and 1994 programs, follow their lead, and support their calls for equal funding (Lee 2013).

Building the work of the economist Elinor C. Ostrom, Peter Levine (2019) writes that "what can we do?" is the most important question facing citizens, with citizen defined as anyone who seriously takes up this question. The question's emphasis on groups ("we") and action ("do") shifts focus away from what should happen, or what governments should do, towards what we can and must do to transform 
society and government policy through participation in organizations and networks in ways that we, through deliberation with others, define as right and good. We may need to create new groups and adopt group principles that facilitate effective deliberation and action. For Ostrom, Levine further explains, processes and means, strategies and tactics of change and self-governance, matter more than "fully specified ideals of a good society" (106).

Ostrom's "we" implicates everyone, requiring personal commitments to courses of group action to catalyze the changes we seek, in this case, to transform Extension programs. As faculty at a land grant institution, I can engage in public dialogue with Extension leadership and Extension agents about values and partners, including writing this essay, and work with them to discuss possibilities for alternative programs and implementation; organize forums with participants representing different Extension institutions, interested faculty, and community partners to discuss Extension's contradictory history and its potential as a platform for transformative engagement; work through shared governance, faculty alliances, and community networks to build a coalition to institutionalize a new vision for Extension; and lobby university administrators, local, regional, state, and national political leaders to embrace a liberatory vision.

In what follows, I describe what Liberation Extension might look like in practice, focusing on programs for agriculture, mutual aid, and rapid decarbonization.

\section{Extension and transition}

\section{Transforming the food system}

The dominant global food regime is controlled by powerful corporate monopolies-agribusiness and retail-whose quest to maximize profits by producing ever-expanding quantities of standardized food commodities exploits farmers, workers, animals, and taxpayers, and is a leading driver of ecological harm, climate change, and global hunger, which is exacerbated, not solved, by increased production (Freidmann 2005; McMichael 2009). Extension helps farmers adapt to regulations, shifting demand, to access markets, adopt new technologies and inputs, cope with climate change, and recently to mitigate sanitary risks during the COVID 19 pandemic, and more, but it does not address the structural violence of the food regime.

Commercial agriculture drains aquifers (Basso et al. 2013) while extreme weather caused by global warming threatens multiple breadbasket failure (Gaupp et al. 2019). Commercial monocultures rely heavily on herbicides and chemical fertilizers that deplete soils (Armundson et al. 2015), drive adaptive evolution in plants and weeds (Gould, Brown and Kuzma 2018), kill beneficial insects and pollinators (Woodcock et al. 2016), and contaminate water systems (Parris 2011). Petroleum-based fertilizers, alongside deforestation, soil depletion, industrial meat production, and global supply chains, make agriculture a major contributor to global warming (Tubiello et al. 2013; Amundson et al. 2015). High-volume, high-speed industrial meat processing disproportionately pollutes poor and nonwhite communities (Wendee 2013), causes unfathomable animal suffering, cultivates super bacteria, and facilitates animal to human contagion, making it a likely source of the next pandemic (Davis 2006; Croft et al 2007; FAO 2013, Wallace et al. 2020). The first affected will be a hyper-exploited, primarily non-white, non-unionized workforce (Striffler 2005; Stuesse 2016), including an overwhelming number of Indigenous Central American immigrants, who, like many farmers in the Global South, are displaced by political violence, transnational land grabs, the dumping of subsidized agricultural overproduction that undercuts subsistence agriculture, and by global warming (Copeland 2020). Meanwhile, US farmers face intense pressure from retail and agribusiness monopolies to cut prices, decreasing their profits and driving consolidation through the supply chain (Howard 2006; Moss and Taylor 2014; Hendrickson et al. 2017).

Extension programs do too little to alter these structural conditions or promote alternatives. At worst, 1862 Extension programs subsidize corporate agriculture, and historically helped to consolidate a small but influential group of overwhelmingly white farmers who understand their interests as aligned with the corporate food system and who lobby against regulation and alternatives (Patel and Goodman 2019). Clark et al. (2017) found that Extension educators working in alternative food systems focused mainly on including excluded groups into the current market-oriented system. Using Stevenson et al.'s (2007) formulation, they contend that Extension educators are pragmatic "builders" of local projects and networking "weavers," but rarely "warriors" for food system transformation, citing a lack of resources, alliances, and administrative support to pursue structural changes, as well as a unifying frame.

Like the food crisis of 2008, the disruptions of COVID 19 and global warming create a moment for convergence between progressive and radical trends in the food system (Holt-Giménez and Shattuck 2011; Niewolny 2021). Extension should build on this moment by devoting significant energy and resources to support a transition to community agriculture, prioritizing marginalized communities, and agroecological production for domestic consumption and local markets to feed the growing underclass. Such efforts have great potential to reduce poverty and inequality, increase food security, mitigate global warming, and provide a viable alternative to the corporate food regime, while 
building broad and diverse coalitions for transformational change.

Agroecology blends ecological and social sciences to design sustainable food systems, foregrounding bio diversity, organic inputs, Indigenous knowledge, and gender parity, among other core principles (Altieri and Rosset 2018). Scaled up, agroecology can help end poverty and hunger and help mitigate global warming by enriching soils that sequester carbon and by using fewer fossil fuels. It also uses far fewer pesticides and herbicides, uses water more efficiently than industrial agriculture, and is more resilient to climate change (Altieri et al. 2015). Extension could simultaneously work to mitigate the racial biases in regenerative agriculture by centering Black and Indigenous agricultural knowledge (Wozniacka 2021).

Liberation Extension could help strengthen alliances between alternative food networks, fostering a "transformative orientation" for food justice that seeks synergy among local initiatives (Levkoe 2011). Through Food System Economic Partnerships, Extension could teach critical perspectives on the history, political economy, and ecological impact of industrial agriculture and the suppression of viable alternatives to diverse stakeholders to catalyze food system transformation (Colasanti et al. 2009). Liberation Extension could train and empower a new generation of agents and community leaders to advocate for substantive change in the food system and implement it through CSAs, urban agriculture, food pantries, and farm to school programs, scaling up through land trusts and cooperatives.

These coalitions could lobby for federal policies conducive to alternative food systems, such as subsidies for agroecology, which would enable small producers to compete on price with agribusiness, approving SNAP benefits for farmers markets, as well as fighting for land access, scale sensitive regulatory standards, and more (Clark et al. 2017). These coalitions could lobby against agribusiness subsidies and support environmental and labor protections, countering the Farm Bureau's influence, while making the case for alternative land use and ownership regimes in solidarity with Black and Indigenous struggles for land and selfdetermination. In these and more ways, Liberation Extension could work to reorganize common sense around agriculture, and help "stich together a coalition that can challenge the dominant mode of agriculture and create a more just food system" (Patel and Goodman 2019). This is vital to addressing climate change, would significantly reduce rural poverty in the US and benefit subsistence agriculture in the Global South, and anticipates the economic and food system disruptions from global warming which will require a shift to small farming "as multitudes of people look for localized low carbon work" (Smaje 2020, p. 34).

Liberation Extension in agriculture weaves together goals of social justice and sustainability in a democratic vision of food sovereignty while furthering decarbonization. The alternative food movement is a touchstone of broader movements for social change, whose collective success is necessary to achieve the democratization of land and water resources and public sector support to achieve true food sovereignty (Patel 2009; Holt-Giménez and Shattuck 2011). This echoes proposals from the Biden Administration to promote regenerative agriculture to sequester carbon, but goes further to build ties between diverse communities, challenge the corporate food regime and materialize brighter futures in transitional processes.

\section{Mutual aid}

Fallout from COVID 19 spurred the expansion and creation of numerous mutual aid networks, where community members come together to help each other with basic needs, from clothing, food, plumbing, transportation, to short term housing (Springer 2020). The popularization of mutual aid prior to COVID 19 speaks to growing material need in a starkly unequal society where social protections have been slashed. Mutual aid cuts against the core values of capitalist society that elevates individual competition in markets as the route to prosperity through economic growth. Mutual aid embodies the values of caretaking, sharing, reciprocity, and prioritizes human needs and collective well-being over profit (Spade 2020). Mutual aid creates a refuge from the free market and brings people together for a common purpose and has considerable potential to weave community bonds, expand organizational capacity, and build critical common sense while protecting the vulnerable.

Mutual aid is limited, however, bypasses some communities entirely, and its long-term stability is not clear. Extension has the logistical know-how and community ties to strengthen existing mutual aid and support networks and to create new initiatives where needed. Liberation Extension could build more durable networks that reach more isolated groups with dedicated, paid support staff who could help coordinate volunteers, donations, trades, and other forms of mutual assistance. Liberation Extension could simultaneously educate communities about the policies that contribute to collective inequality and vulnerability and the potential of alternative economic frameworks and build ties with organizations that advocate for them.

Mutual aid, transformed food systems, and Extension could productively converge in community kitchens for working and low-income families. Liberation Extension can provide recipes and coordinate training for families who take turns cooking healthy meals for large groups, procure kitchen space and materials, and organize self-sustaining organizations with direct links to local farmers. Community kitchens could save time and money, help mitigate food 
insecurity and food deserts, and build food sovereignty and community solidarity.

Global warming underscores the need for mutual aid to address the human impact of disasters, which are anything but natural. The routinization of annual wildfires, heat domes, deep freezes, hurricanes, 500-year floods, and drought make clear how unprepared we are for climate catastrophe. Conversations around infrastructure have overlooked the social infrastructure of caretaking that is required to address needs, for shelter, food, first aid, and more, that persist after the Federal Emergency Management Agency (FEMA) leaves. Liberation Extension could help train emergency responders and local and regional response units, connect communities to resources through mutual aid, educate communities about local risks from climate change, and help them develop harm reduction strategies while building political coalitions for extended relief and decarbonization.

Critics argue that mutual aid risks letting the government off the hook, substituting private resiliency for redistributive politics and functioning safety nets (Wuest 2020). Helping each other out has limits when divorced from organized efforts to demand resources for poor communities. Liberation Extension would promote mutual aid as a platform for collective deliberation, education, and organizing for redistributive public investment in housing, health care, and infrastructure, alternative agriculture, strengthened labor rights and environmental protections, and for policies to address climate change.

\section{Climate change mitigation}

An important synergistic task for Liberation Extension is to mobilize society for rapid decarbonization to mitigate global warming. Extension could help implement and shape the Civilian Conservation Corps established by President Biden's executive order that aims to create well-paying jobs in conservation, reforestation, remediation, and infrastructure, such as a decentralized electrical grid for renewable energy, constructing zero carbon homes, and weatherization. Liberation Extension could teach about environmental justice, the political economy of fossil fuels, and the kinds of economic, energy, agricultural, housing, and transportation systems necessary to avoid the worst outcomes, while promoting organizing to demand a far reaching climate transition complete with well-paying jobs for workers in polluting industries. A full treatment of Liberation Extension's potential for climate change mitigation and ecological restoration is beyond the scope of this essay, but it could play an important role in promoting postgrowth economic common sense and creating movements for decarbonization.

\section{Conclusion}

My aim has been to highlight the dangers and opportunities in the current historic moment, connect Extension to discussions of transition, and highlight dialogues internal to Extension in hopes of building on existing liberatory initiatives and impulses. As Extension expands, it can respond to the needs of broader constituencies to build the organizational capacity for a transformed economy and society, or it can continue to support harm reduction in an unequal and destructive system. Neutrality is not an option. Liberation Extension is also an important step toward redefining the public land grant mission to include cultivating responseability for collaboratively formulating just and sustainable public responses to pressing problems. This is an ethical stance given the foundation of land grants through Indigenous dispossession and Extension's role in creating exclusionary and unsustainable economic systems and empowering reactionary farmer organizations. Working collectively to undo these legacies is the path to creating a more just and sustainable society.

We are in a key moment when there is space and urgency to collectively reimagine what Extension could and should be, building on the good and learning from the bad from the past. This rethinking must start with the recognition that dominant social and economic systems have produced harms and are now collapsing, creating problems that far outstrip the range of solutions from within these systems. COVID 19 has revealed that we are indeed capable of making dramatic changes on short notice, many of them long overdue, and that when the government fails to act, communities can step up to take care of one another. But we must use this opening to build far-reaching alliances for civilizational transition lest we continue to privatize and racialize the burden of societal and ecological collapse. I hope to combine the growing sense we must act boldly with the optimism that viable alternatives exist and that we can reorganize public institutions to help bring them to scale.

Acknowledgements I want to thank the Virginia Cooperative Extension leadership team, Ed Jones, Cathy Sutphin, Ben Grove, and Dan Goerlich for their patience and feedback. I am also thankful to Kim Niewolny for support for this project and for inviting me to participate in the Center for Food Systems and Community Transformation speaker series, to Scott Peters for encouragement and suggestions, to Ric MacDowell for sharing wisdom and experience, and to Judson Abraham and Bailey Villareal for their assistance. The essay also benefitted from generous feedback from three anonymous reviewers. I take responsibility for errors and omissions. 


\section{References}

Ahtone, Tristan, and Robert Lee. 2021. Looking Forward from LandGrab Universities. Native American and Indigenous Studies. 8 (1): 176-182.

Ajl, Max. 2020. A People's Green New Deal. London: Pluto Press.

Altieri, Miguel A., Clara I. Nicholls, Alejandro Henao, and Marcos A. Lana. 2015. Agroecology and the Design of Climate ChangeResilient Farming Systems. Agronomy for Sustainable Development. 35 (3): 869-890.

Altieri, Miguel A., and Clara I. Nicholls. 2012. Agroecology Scaling Up for Food Sovereignty and Resiliency. In Sustainable Agriculture Reviews, 1-29. Dordrecht: Springer

Altieri, Miguel A., and Peter M. Rosset. 2018. Agroecology: Science and Politics. Black Point, Nova Scotia: Fernwood Publishing.

Andrasfay, Theresa, and Noreen Goldman. 2021. Reductions in 2020 US Life Expectancy due to COVID-19 and the Disproportionate Impact on the Black and Latino Populations. Proceedings of the National Academy of Sciences. 118 (5): e2014746118. https://doi. org/10.1073/pnas.2014746118.

Amundson, Ronald, Asmeret Asefaw Berhe, Jan W. Hopmans, A. Carolyn Olson, Ester Sztein, and Donald L. Sparks. 2015. Soil and Human Security in the 21st Century. Science 348: 6235.

Aronoff, Kate, Alyssa Battistoni, Daniel Aldana Cohen, and Thea Riofrancos. 2019. A Planet to Win: Why We Need a Green New Deal. London: Verso Books.

Atwoli, Lukoye, Abdullah H. Baqui, Thomas Benfield, Raffaella Bosurgi, Fiona Godlee, Stephen Hancocks, Richard Horton, Laurie Laybourn-Langton, Carlos Agosto Monteiro, Ian Norman, Kristen Patrick, and Nigel Praities. 2021. Call for Emergency Action to Limit Global Temperature Increases, Restore Biodiversity, and Protect Health. Journal of Health, Population and Nutrition. 40 (1): 39.

Attwood, Sophie, and Cother Hajat. 2020. How Will the COVID-19 Pandemic Shape the Future of Meat Consumption? Public Health Nutrition 2 (17): 3116-3120.

Bailey, Liberty Hyde. 1903. The Nature-Study Idea. New York: Doubleday, Page and Company.

Bailey, Liberty Hyde. 1915/1980. The Holy Earth. Ithaca, NY: New York State College of Agriculture and Life Sciences.

Barnosky, Anthony D., Nicholas Matzke, and Susumu Tomiya. 2011. Has the Earth's Sixth Mass Extinction Already Arrived? Nature 471: 51-57. https://doi.org/10.1038/nature09678.

Basso, Bruno, Anthony D. Kendall, and David W. Hyndman. 2013. The Future of Agriculture over the Ogallala Aquifer: Solutions to Grow Crops More Efficiently with Limited Water. Earth's Future 1 (1): 39-41.

Bellamy Foster, John and Intan Suwandi. 2021. COVID 19 and Catastrophe Capitalism. Monthly Review, June 1. https://monthlyreview. org/2020/06/01/covid-19-and-catastrophe-capitalism/

Bellamy Foster, John. 2000. Marx's Ecology. New York: Monthly Review Press.

Bordera Romá, Juan. 2021. The IPCC Links and Unbridled Capitalism. Resilience, September 2. https://www.resilience.org/stories/202109-02/the-ipcc-leaks-and-unbridled-capitalism/

Boyd, John, and Scott Faber. 2020. The Farm Bureau Says It Wants to Fight Racism. Here's Where to Start. Civil Eats, July 3. https:// civileats.com/2020/07/03/op-ed-the-farm-bureau-says-it-wantsto-fight-racism-heres-where-to-start/

Brown, Wendy. 2015. Undoing the Demos: Neoliberalism's Stealth Revolution. New York: Zone Books.

Byanyima, Winnie. 2021. A Global Vaccine Apartheid is Unfolding. People's Lives Must Come Before Profit. The Guardian, January 29. https://www.theguardian.com/global-development/ 2021/jan/29/a-global-vaccine-apartheid-is-unfolding-peopl es-lives-must-come-before-profit

Campbell, C.M. 1962. The Farm Bureau and the New Deal: A Study in the Making of National Farm Policy, 1933-40. Urbana: University of Illinois Press.

Cassidy, John. 2021. The Biden White House is Tossing Obama's Economic Playbook. The New Yorker, February 11.

Clark, Kill, Molly Bean, Samina Raja, Scott Loveridge, Julia Freedgood, and Kimberley Hodgson. 2017. Cooperative Extension and Food System Change: Goals, Strategies, and Resources. Agriculture and Human Values. 34: 310-316.

Colasanti, Kathryn, Wynne Wright, and Brenda Reau. 2009. Extension, the Land-Grant Mission, and Civic Agriculture: Cultivating Change. Journal of Extension. 47 (4): 1-10.

Colvin, Jill. 2020. President Trump Will Order Meat Processing Plants to Remain Open. Salt Lake Tribune, April 28.

Copeland, Nicholas. 2012. Greening the Counterinsurgency: The Deceptive Effects of Guatemala's Rural Development Plan of 1970. Development and Change. 43 (4): 975-998.

Copeland, Nicholas. 2019. The Democracy Development Machine: Neoliberalism, Radical Pessimism and Authoritarian Populism in Mayan Guatemala. Ithaca, NY: Cornell University Press.

Copeland, Nicholas. 2020. A New Deal for Central America. NACLA Report on the Americas. 52 (1): 67-76.

Coppess, Jonathan, Gary Schnitkey, Nick Paulson, and Carl Zulauf. 2018. Reviewing the CBO Baseline for 2018 Farm Bill Debate. Farmdoc Daily (8): 65. Department of Agricultural and Consumer Economics, University of Illinois at Urbana-Champaign. https:// farmdocdaily.illinois.edu/2018/08/farm-bill-food-for-thoughtresearch-and-extension.html (accessed May 3, 2021)

Croft, Arthur C., Anthony V. D'Antoni, and Stephanie L. Terzulli. 2007. Update on the Antibacterial Resistance Crisis. Medical Science Monitor 13 (6): RA103-RA118.

Davis, Mike. 2006. The Monster at Our Door: The Global Threat of Avian Flu, 2006. New York: Macmillan.

Davis, Mike. 2020. The Coronavirus is a Monster Fueled by Capitalism. In These Times, March 20. https://inthesetimes.com/article/ coronavirus-crisis-capitalism-covid-19-monster-mike-davis

Food and Agriculture Organization (FAO). 2013. Surge in Diseases of Animal Origin Necessitates New Approach to Health. Rome: United Nations.

Friedmann, Harriet. 2005. Feeding the Empire: The Pathologies of Globalized Agriculture. Socialist Register. 41: 207-225.

Gaupp, Franziska, Jim Hall, Dann Mitchell, and Simon Dadson. 2019. Increasing Risks of Multiple Breadbasket Failure under 1.5 and 2 C Global Warming. Agricultural Systems 175: 34-45.

Goerlich, Dan, and Martha A. Walker. 2015. Determining Extension's Role in Controversial Issues: Content, Process, Neither, or Both? Journal of Extension 53 (3): n3.

Gould, Fred, Zachary S. Brown, and Jennifer Kuzma. 2018. Wicked Evolution: Can we Address the Sociobiological Dilemma of Pesticide Resistance? Science 360 (6390): 728-732.

Grant, Gary R., Spencer D. Wood, and Willie J. Wright. 2012. Black Farmers United: The Struggle against Power and Principalities. The Journal of Pan African Studies. 5 (1): 1-20.

Gutierrez, Gustavo, Caridad Inda, John Eagleson, and Caridad Inda. 1988. A Theology of Liberation: History, Politics, and Salvation. Maryknoll, NY: Orbis Books.

Hale, Charles R. 2006. Activist Research v. Cultural Critique: Indigenous Land Rights and the Contradictions of Politically-Engaged Anthropology. Cultural Anthropology. 21 (1): 96-120.

Haraway, Donna. 2016. Staying with the Trouble: Making Kin in the Chtuluchene. Durham: Duke University Press.

Haraway, Donna, Noboru Ishikawa, Scott F. Gilbert, Kenneth Olwig, Anna L. Tsing, and Nils Bubandt. 2016. Anthropologists are Talking-About the Anthropocene. Ethnos 81 (3): 535-564. 
Harris, Carmen V. 2008. The Extension Service is Not an Integration Agency": The Idea of Race in the Cooperative Extension Service. Agricultural History. 82 (2): 193-219.

Harvey, David. 2006. Neo-liberalism as Creative Destruction. Geography Annaler Series B 88 (2): 145-158.

Hendrickson, Mary, Philip H. Howard, and Douglas Constance. 2017. Power, Food and Agriculture: Implications for Farmers, Consumers and Communities. SSRN. https://ssrn.com/abstract $=30660$ 05 or https://doi.org/10.2139/ssrn.3066005

Hickel, Jason. 2020. Less is More: How Degrowth Will Save the World, 2020. New York: Random House.

Howard, Phil. 2006. Consolidation in Food and Agriculture: Implications for Farmers \& consumers. The Natural Farmer 2 (68): $17-20$.

Holt-Giménez, Eric, and Annie Shattuck. 2011. Food Crises, Food Regimes and Food Movements: Rumblings of Reform or Tides of Transformation? The Journal of Peasant Studies 38 (1): 109-144.

INFAS. 2018. A Deeper Challenge of Change: The Role of Land-Grant Universities in Assessing and Ending Structural Racism in the US Food system, Inter-institutional Network for Food, Agriculture, and Sustainability (INFAS). February https://asi.ucdavis.edu/ programs/infas/a-deeper-challenge-of-change-the-role-of-landgrant-universities-in-assessing-and-ending-structural-racism-inthe-us-food-system (accessed May 3, 2020)

Intergovernmental Panel on Climate Change (IPCC). 2021. Special Report: Global Warming of 1.5 Celsius. https://www.ipcc.ch/sr15/

Kallis, Giorgos, Susan Paulson, Giacomo D’Alisa, and Federico Demaria. 2020. The Case for Degrowth. New York: Wiley.

Kaplan, Juliana. 2021. Workers Lost 3.7 Trillion in the Pandemic. Women and Gen Z Saw the Biggest Losses. Business Insider, January 25. https://www.businessinsider.com/workers-lost-37-trill ion-in-earnings-during-the-pandemic-2021-1

Kile, Orville M. 1948. The Farm Bureau Through Three Decades. Baltimore: The Waverly Press.

Lee, John Michael. 2013. Land-Grant but Unequal: State One-to-One Matching for 1890 Universities. Association of Public Land Grant Universities Policy Brief, September https://www.aplu.org/library/ land-grant-but-unequal-state-one-to-one-match-funding-for-1890land-grant-universities/file

Levkoe, Charles Z. 2011. Towards a Transformative Food Politics. Local Environment. 16 (7): 687-705.

Levine, Peter. 2019. 'What Should We Do?' The Bloomington School and the Citizen's Core Question In Ostrom's Tensions: Reexamining the Political Economy and Public Policy of Elinor Ostrom, ed. Roberta Herzberg, Peter J. Boettke, and Paul Dragos Aligica, 105125. Arlington, VA: Mercatus Center at George Mason University.

McMichael, Philip. 2009. A Food Regime Genealogy. The Journal of Peasant Studies. 36 (1): 139-169.

Mehta, Jonaki and Alisa Chang. 2020. For Hungry Americans, Food Insecurity Crisis Deepens. NPR. All Things Considered, December 14. https://www.npr.org/sections/coronavirus-live-updates/ 2020/12/14/946420784/u-s-faces-food-insecurity-crisis-as-sever al-federal-aid-programs-set-to-run-out

Moore, Jason. 2015. Capitalism in the Web of Life: Ecology and the Accumulation of Capital. London: Verso.

Moss, Diana L., and C. Robert Taylor. 2014. Short Ends of the Stick: The Plight of Growers and Consumers in Concentrated Agricultural Supply Chains. Wisconsin Law Review, 337.

National Congress of the American Indian. 2015. In Support of Equity in Federal Funding for 1994 Land-Grant Institutions and Indian Extension Agent Programs. Resolution SD-15-077. Indian Higher Education Consortium. https://www.ncai.org/resources/resol utions/in-support-of-equity-in-federal-funding-for-1994-landgrant-institutions-tribally-chartered-college-universities-andindian-extension-agent-programs
Navarro, Vicente. 2020. The Consequences of Neoliberalism in the Current Pandemic. International Journal of Health Services 50 (3): 271-275.

Niewolny, Kim. 2021. Boundary Politics and the Social Imaginary for Sustainable Food Systems. Agriculture and Human Values. 2021: 1-4. https://doi.org/10.1007/s10460-021-10214-0.

Ostrom, M. 2020. Radical Roots and Twenty-first Century Realities: Rediscovering the Egalitarian Aspirations of Land Grant University Extension. Agriculture and Human Values 37: 935-943. https://doi.org/10.1007/s10460-020-10163-0.

Oxfam. 2021. Mega-rich Recoup COVID-losses in Record Time Yet Billions Will Live in Poverty for at Least a Decade. Oxfam International Press Release, January 25

Parris, Kevin. 2011. Impact of Agriculture on Water Pollution in OECD Countries: Recent Trends and Future Prospects. International Journal of Water Resources Development. 27 (1): 33-52.

Patel, Raj. 2009. Grasroots Voices: What does Food Sovereignty Look Like? Journal of Peasant Studies. 36 (3): 663-706.

Patel, Raj and Jim Goodman. 2019. A Green New Deal for Agriculture. Jacobin, April 4. https://www.jacobinmag.com/2019/04/ green-new-deal-agriculture-farm-workers/.

Peters, Scott J. 2006. Every Farmer Should Be Awakened: Liberty Hyde Bailey's Vision of Agricultural Extension Work. Agricultural History 80: 190-219.

Peters, Scott J. 2014. Extension Reconsidered. Choices Agriculture \& Applied Economics Association 29 (1): 1-6.

Peters, Scott. 2021. Leading Through Extension: Experimenting Together. Extension Out Loud. Cornell Cooperative Extension. https://cals.cornell.edu/news/leading-through-extension-exper imenting-together (accessed May 3, 2021)

Peters, Scott, Theodore Alter, and Timothy Shaffer. 2018. Jumping into Civic Life: Stories of Public Work from Extension Professionals. Dayton: Kettering Foundation Press.

Raderstorf, Alia Mcpherson. 2020. A Green New Deal for Agriculture: The American Farm Bureau and the American Farmer. Honors Thesis. Arizona State University.

Raworth, Kate. 2017. Doughnut Economics: Seven ways to Think Like a 21 st-Century Economist. White River Junction: Chelsea Green Publishing.

Red Nation. 2021. The Red Deal: Indigenous Action to Save Our Earth. New York: Common Notions.

Rose, Nikolas. 1999. Powers of Freedom: Reframing Political Thought. Cambridge: Cambridge University Press.

Schlesinger, Jacob, and Andrew Restuccia. 2021. Behind Biden's Plans: Belief that Government Can Drive Growth. Wall Street Journal, March 30.

Serwer, Adam. 2020. The Coronavirus was an Emergency Until Trump found Out Who Was Dying. The Atlantic, May 8. https:// www.theatlantic.com/ideas/archive/2020/05/americas-racialcontract-showing/611389/

Shearn, Ian. 2012. Whose Side is the American Farm Bureau On? The Nation, July 16.

Smaje, Chris. 2020. A Small Farm Future: Making the Case for a Society Build around Local Economies, Self-Provisioning, Agricultural Diversity, and a Shared Earth. London: Chelsea Green.

Smith, Ruby Green. 1949. The People's Colleges: A History of the New York State Extension Service in Cornell University and the State 1876-1948, 2013th ed. Ithaca, NY: Cornell University Press and Fall Creek Books.

Spade, Dean. 2020. Building Solidarity During this Crisis, (and the Next). London: Verso.

Springer, Simon. 2020. Caring Geographies: The Covid Interregnum and the Return to Mutual Aid. Dialogues in Human Geography. 10 (2): 112-115. https://doi.org/10.1177/2043820620931277.

Stein, Sharon. 2017. A Colonial History of the Higher Education Present: Rethinking Land-Grant Institutions Through Processes 
of Accumulation and Relations of Conquest, Critical Studies in Education, December, 1-17.

Stevenson, G.W., Kathryn Ruhf, Sharon Lezberg, and Kate Clancy. 2007. Warrior, Builder, and Weaver Work. In Remaking the North American Food System: Strategies for Sustainability, ed. Clare Hinrichs and Thomas Lyson, 33-64. Lincoln and London: University of Nebraska Press.

Striffler, Steve. 2005. Chicken: The Dangerous Transformation of America's Favorite Food. New Haven: Yale University Press.

Stuesse, Angela. 2016. Scratching out a Living: Latinos, Race, and Work in the Deep South. Berkeley: University of California Press.

Taylor, Keeanga-Yamahtta. 2016. From\# BlackLivesMatter to black liberation. Chicago: Haymarket Books.

Tubiello, Francesco N., Mirella Salvatore, Simone Rossi, Alessandro Ferrara, Nuala Fitton, and Pete Smith. 2013. The FAOSTAT Database of Greenhouse Gas Emissions from Agriculture. Environmental Research Letters 8 (1): 015009.

Wallace, Rob, Alex Liebman, Luis Fernando Chaves, and Rodrick Wallace. 2020. COVID 19 and the Circuits of Capital, Monthly Review, May 1. https://monthlyreview.org/2020/05/01/covid-19and-circuits-of-capital/

Wang, Sun Ling. 2014. The Cooperative Extension System: Trends and Economic Impacts on US Agriculture. Choices 29 (316): 1-8.

Wendee, Nicole. 2013. CAFOs and Environmental Justice: The Case of North Carolina. Environmental Health Perspectives. 121 (6): a182-a189.

Whayne, Jeannie M. 1988. Black Farmers and the Agricultural Cooperative Extension Service: The Alabama Experience, 1945-1965. Agricultural History. 72 (3): 523-551.

Woodcock, Ben, Nicholas Isaac, James Bullock, et al. 2016. Impacts of Neonicotinoid Use on Long-Term Population Changes in Wild
Bees in England. Nature Communications. 7: 12459. https://doi. org/10.1038/ncomms12459.

Woodhandler, Steffie, David Himmelstein, Sameer Ahmed, Zinzi Bailey, Mary Basset, Michael Bird, et al. 2021. Public Policy and Health in the Trump Era". Lancet Commission. the Lancet. 397 (10275): 705-753.

World People's Congress on Climate Change and the Rights of Mother Earth. 2010. Cochabomba, Bolivia. https://pwccc.wordpress.com/ (accessed January 7, 2022)

Wozniacka, Gosia. Does Regenerative Agriculture have a Race Problem? Civil Eats, January 5. https://civileats.com/2021/01/05/doesregenerative-agriculture-have-a-race-problem/

Wuest, Joanna. 2020. Mutual Aid Can't Do It Alone. The Nation, December 16

Publisher's Note Springer Nature remains neutral with regard to jurisdictional claims in published maps and institutional affiliations.

Nicholas Copeland is a political anthropologist whose book, The Democracy Development Machine (Cornell University Press, 2019), examines how violent forms of development extend counterinsurgency through electoral democracy in Guatemalan Mayan communities. He currently studies the significance of water and community water science in Indigenous environmental movements against extractive industries. 